\title{
[一般論文 $]$
}

\section{酢酸コバルトをコバルト源とした CO 水素化用 $\mathrm{Co}-\mathrm{Re}-\mathrm{Sr} / \mathrm{SiO}_{2}$ 触媒のキャラクタリゼーション}

\author{
松崎武彦*，竹内和彦，花岡隆昌，荒川裕則，杉 義弘 \\ 物質工学工業技術研究所, 305 茨城県つくば市東 1-1
}

(平成 5 年 7 月 9 日受理)

\begin{abstract}
$\mathrm{Co}, \mathrm{Re}, \mathrm{Sr}$ はそれぞれ単独でシリカに担持されても $\mathrm{CO}$ 水素化活性をほとんど持たないが, $\mathrm{Co}-\mathrm{Re} / \mathrm{SiO}_{2}$ は高い 炭化水素生成活性と $10 \%$ 程度のエ夕ノール選択率を示すようになり，さらにこれに Sr を加えた触媒はエ夕ノール 選択率を大幅に向上させた（エ夕ノール選択率約 $25 \%$ )。反応結果から，Co と Re の共存により新たに CO 水素化 に活性なサイトが形成され，Sr は炭化水素の生成を抑え，エ夕ノール生成を促進する役割を有すると考えられた。 この触媒系の活性種の性質や各成分の役割を調べることを目的として，XRD，XPS，ESR，可視スペクトル (VIS)，TG，TPR 等によりキャラクタリゼーションを行い，以下のことが明らかとなった。(1)Co と Re の共存に より, $\mathrm{Co}^{2+}$ の一部が $\mathrm{Co}^{0}$ に水素還元されたが， Re には変化が認められなかった。(2)Co は高分散を保持していた (2 nm 以下)。(3) Sr は Co の還元を抑制した。(4)CO 吸着量と水素化活性はよく対応した。以上の結果より，(1) $\mathrm{CO}$ 水素化の主たる活性種は高分散金属状 Co である，(2)Re はシリカ上で安定な不活性 $\mathrm{Co}^{2+}$ の活性な金属 Co 一 の還元を援ける，(3)Sr は触媒の水素化能を低下させるとともに，Co の電子状態を制御して，エタノール生成の中 間体であるアシル-Co 錯体を安定化させる, と推定した。
\end{abstract}

\section{1. 緒論}

通常の硝酸コバルトを出発原料とする担持 Co 触媒は高い $\mathrm{CO}$ 解離能と連鎖成長能を持っており，合成ガス反応において 高級炭化水素生成能の高い, いわゆる Fischer-Tropsch 反応触 媒として優れた性能を持つ触媒として知られている1)。近年, 含酸素化合物, 特に $\mathrm{C}_{2}$ 以上のアルコールを目的生成物とする 触媒として Co も注目されるようになったが，その研究例の大 部分はその $\mathrm{CO}$ 解離能と連鎖成長能の高さを利用した, メ夕 ノール合成触媒や MoS 触媒に対する添加物としてであり ${ }^{2)}$, Co を主要な成分とした触媒による含酸素化合物を目的生成物 とする研究例は少ない3)。

しかしながら，触媒の性質はしばしば，その出発原料，調製 法, 担体の種類等によって大きく異なることがあり, Co 触媒

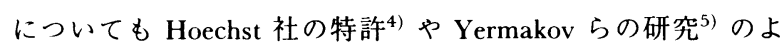
うに含酸素化合物を主要生成物とした触媒はいずれもCo の出 発原料や担体等に特徵を持っている。我々もこれまで, 酢酸コ バルトから調製した $\mathrm{Co} / \mathrm{SiO}_{2}$ はそれ自身では $\mathrm{CO}$ 水素化活性 は小さいが, 硝酸コバルトや塩化コバルトから調製した $\mathrm{Co} / \mathrm{SiO}_{2}$ に比べて特異な $\mathrm{Co}$ の分散度や $\mathrm{Co}$ の電子状態を持つ こと吕－8)，また $\mathrm{Re}, \mathrm{Ru}, \mathrm{Ir}$ 等の遷移金属と $\mathrm{Sr}$ 等のアルカリ 土類金属で二重に修飾された $\mathrm{Co} / \mathrm{SiO}_{2}$ 触媒が, 高いエ夕ノー ル生成活性を持つことを報告してきだ) -13)。すなわち，酢酸 コバルトから調製した $\mathrm{Co} / \mathrm{SiO}_{2}$ は合成ガス反応に対する活性 は低く，少量の幅広い炭素数を持つ炭化水素を生成するのみで あった。一方, Re や Ir は単独で $\mathrm{SiO}_{2}$ に担持してもさらに活 性が低く，それぞれ少量のメタン，メタノールを主として生成 し, Ru は活性は高いが生成物はほとんど高級炭化水素であっ た。しかし，Coにこれらの遷移金属を共存させた触媒では活
性がこれらの単独の場合に比べて大きく向上するだけでなく， 炭化水素のほかエタノール等の含酸素化合物も生成されるよj になった (エタノール選択率 $10 \%$ 程度 $)^{9) ー 11) 。 さ ら に, ~ こ れ ~}$ らに $\mathrm{Sr}$ 等のアルカリ土類金属を加えた触媒では，炭化水素の 生成が大幅に減少し, エタノールの選択率が $25 \sim 40 \%$ 程度ま で向上した。これまで $\mathrm{Co}-\mathrm{Ru} / \mathrm{SiO}_{2}$ や $\mathrm{Co}-\mathrm{Ir} / \mathrm{SiO}_{2}$ 触媒につい て個別に検討した結果から, $\mathrm{Ru}$ や Ir は $\mathrm{SiO}_{2}$ 上の不活性な $\mathrm{Co}^{2+}$ を活性な $\mathrm{Co}^{0}$ に還元する役割を持つと考えられ た ${ }^{12), 13) 。 ~}$

これまでの反応結果から、これら Re，Ru，Irに修飾された Co 触媒は互いに類似した性質の活性点を持ち, Re, Ru, Ir は共通の役割を持つものと考えられた。そこで今回は，本触媒 系の活性種とその性質拉よび $\mathrm{Sr}$ を含めた各成分元素の役割を より一層明らかにすることを目的として, $\mathrm{Co}-\mathrm{Re}-\mathrm{Sr} / \mathrm{SiO}_{2}$ 触 媒について各種のキ+ラクタリゼーションを行った。

\section{2. 実験}

\section{1. 触媒の調製}

触媒は, すべて $\mathrm{SiO}_{2}$ (Davison \#57，16〜32 メッシュ, 比 表面積 $330 \mathrm{~m}^{2} / \mathrm{g}$ ) を担体とし，含浸法により調製した。 $\mathrm{Co} / \mathrm{SiO}_{2}$ 触媒は, $200^{\circ} \mathrm{C}$ で加熱排気した $\mathrm{SiO}_{2} に \mathrm{SiO}_{2}$ の 1.5 倍重量の水に溶かした所定量の酢酸コバルト（Co $\left(\mathrm{OCOCH}_{3}\right)_{2} \cdot 4 \mathrm{H}_{2} \mathrm{O}$, 和光純薬 $\left.\mathrm{GR}\right)$ を含む水溶液を含浸さ せ, 一昼夜の放置熟成, $50 \sim 120^{\circ} \mathrm{C}$ での排気乾燥の後, 300 $350^{\circ} \mathrm{C}$ で 3 時間水素処理を行って調製した。 Re と Sr は, 過 レニウム酸アンモニウム $\left(\mathrm{NH}_{4} \mathrm{ReO}_{4}\right.$, 和光純薬 $\left.\mathrm{GR}\right)$ と酢酸 ストロンチウム $\left(\mathrm{Sr}\left(\mathrm{OCOCH}_{3}\right)_{2} \cdot 1 / 2 \mathrm{H}_{2} \mathrm{O}\right.$, 和光純薬 GR $)$ の 混合水溶液から同様に $300^{\circ} \mathrm{C}$ 水素処理済みの $\mathrm{Co} / \mathrm{SiO}_{2}$ 上に同 時含浸した。各成分の標準含有量は $\mathrm{SiO}_{2}$ に対して金属換算で 各 $5 \mathrm{wt} \%$ とした。これらの触媒のキャラクタリゼーションは 
原則として CO 水素化反応と同一の前処理 $\left(450^{\circ} \mathrm{C}\right.$ で 3 時間 水素処理）を施してから行った。なお本文中，比較のため硝酸 コバルト $\left(\mathrm{Co}\left(\mathrm{NO}_{3}\right)_{2} \cdot 6 \mathrm{H}_{2} \mathrm{O}\right)$ から調製した $\mathrm{Co} / \mathrm{SiO}_{2}$ を用い る場合のほか, 原料について特別な記載のない $\mathrm{Co} / \mathrm{SiO}_{2}$ はす べて酢酸コバルトを出発原料としたものである。

\section{2. 触媒のキャラクタリゼーション}

\section{2. 1. $\mathrm{H}_{2}$ および $\mathrm{CO}$ の化学吸着贵の测定}

内容積約 $140 \mathrm{ml}$ の閉鎖系ガス循環装置を用い, $400^{\circ} \mathrm{C} て ゙ 2$ 時間水素処理を施した後, 静置法で測定した。

\section{2. 2. $\mathrm{X}$ 線光電子スペクトル (XPS)}

島津製作所製 ASIX-1000 型表面分析装置を用いて測定し た。あらかじめ $450^{\circ} \mathrm{C} て ゙ 3$ 時間水素处理を施した触媒を空気 中で粉砕・加圧成形し，銀ペーストを用いてステンレス製試料 台に接着し, 装置付属の前処理装置中で in situで水素処理 $\left(300^{\circ} \mathrm{C}, 0.5 \mathrm{~h}\right)$ して測定した。AlK $\alpha(1,487 \mathrm{eV})$ を X 線源と して用い, Si2P $(103.4 \mathrm{eV})$ を結合エネルギーの基準とした。

\subsection{3. 電子スピン共鳴（ESR）}

粒状触媒を水素還元処理 $\left(450^{\circ} \mathrm{C}, 3 \mathrm{~h}\right)$ 後そのまま石英製 試料管に入れ，Varian 社製 E12型 ESR を用い液体窒素温度で 測定した。トルエンーピリジン混合溶液に溶解した酢酸コバル トを $\mathrm{Co}^{2+}$ の標準試料とした。

\section{2. 4. 可視スペクトル（VIS）}

水素還元処理した触媒を空気中で粉砕し, セロファン粘着 テープにはりつけ, Carry Model-17 分光光度計を用いて測定 した。測定は $350 \sim 750 \mathrm{~nm}$ 領域を 2 回積算した。

\section{2. 5. 水秦雷囲気下での熱重量分析（TG）}

島津製作所製熱重量測定装置 TGC-30 を用い，約 $10 \mathrm{mg} の$ 粉末試料 (末還元処理触媒) をアルミナ製の皿に入れ，水素気 流中室温から $900^{\circ} \mathrm{C}$ まで昇温した。昇温速度は $20^{\circ} \mathrm{C} / \mathrm{min}$, 水素流量 $50 \mathrm{ml} / \mathrm{min}$ 。

\section{2. 6. 粉末 $\mathrm{X}$ 線回折 (XRD)}

試料触媒を水素還元処理 $\left(450^{\circ} \mathrm{C}, 3 \mathrm{~h}\right)$ してから空気中で粉 砕し, Philips 社製 PW1700 型自動粉末 X 線回折装置の $\mathrm{CuK} \alpha$ 線（ $\lambda=1.542 \mathrm{~A} ）$ を用いて測定した。

\section{2. 7. 吸着 CO の昇温反応脱離（TPR）}

$450^{\circ} \mathrm{C}$ で水素還元処理済みの粒状触媒 $300 \mathrm{mg}$ を試料管に充 てんし, 水素キャリヤー中 $(60 \mathrm{ml} / \mathrm{min}) 7.5^{\circ} \mathrm{C} / \mathrm{min}$ の速度で $400^{\circ} \mathrm{C}$ まで昇温し，その温度で 1 時間保持した。室温まで冷 却してからキャリヤーガスをへリウムに変え, $\mathrm{CO}$ パルスを導 入してその飽和吸着量を測定した。その後再びキャリヤーを水 素に変え, $7.5^{\circ} \mathrm{C} / \mathrm{min}$ で $300^{\circ} \mathrm{C}$ または $350^{\circ} \mathrm{C}$ ま゙昇温し， TCD および FID 検出器で生成物の脱離スペクトルを得た。

\section{3. 結果と考察}

3. 1. 触某のキャラクタリゼーション

\section{1. 1. 水秦, $\mathrm{CO}$ の化学吸着量の测定}

Fig. 1 に各触媒について静置法による水素および CO の化 学吸着量と触媒活性との関係を示す。 $\mathrm{Co} / \mathrm{SiO}_{2}$ は $\mathrm{CO}$ を吸着 するが水素は全く吸着されなかった。 $\mathrm{Co}-\mathrm{Re} / \mathrm{SiO}_{2}$ では $\mathrm{CO}$ の 吸着量が大幅に増大し，水素も相当量吸着するようになった。 これに Srを加えた触媒では CO, 水素吸着量がともに隇少 し,これら吸着量と触媒活性はよい相関関係を示した。

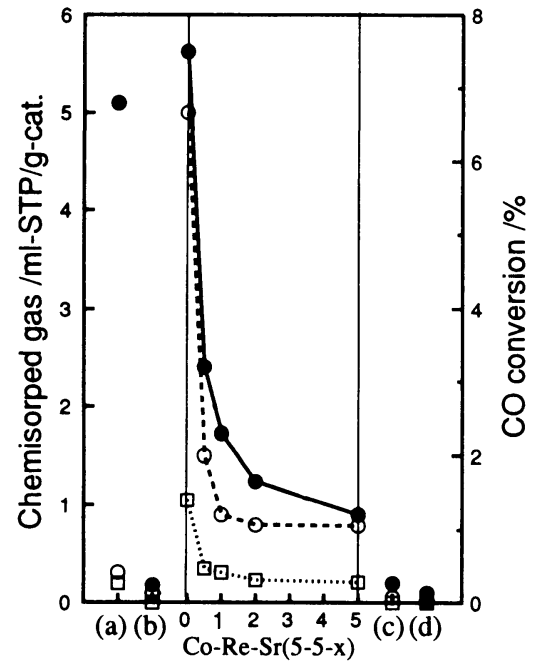

$\bigcirc$ : Adsorption volume of $\mathrm{CO}, \square:$ Adsorption volume of $\mathrm{H}_{2}$. : $\mathrm{CO}$ conversion in the conditions $; \mathrm{CO} / \mathrm{H}_{2} / \mathrm{Ar}=$ $3 / 6 / 1$, Temp. $220^{\circ} \mathrm{C}$, Press. $21 \mathrm{~kg} / \mathrm{cm}^{2}$, GHSV : $2,000 / \mathrm{h}$. (a) $\mathrm{Co} / \mathrm{SiO}_{2}(5 / 100)$ prepared from $\mathrm{Co}\left(\mathrm{NO}_{3}\right) \cdot 6 \mathrm{H}_{2} \mathrm{O}$, (b) $\mathrm{Co} / \mathrm{SiO}_{2}$ (5/100), (c) $\mathrm{Re} / \mathrm{SiO}_{2}(5 / 100)$, (d) $\mathrm{Sr} / \mathrm{SiO}_{2}$ $(5 / 100)$. The influences of $\mathrm{Sr}$ content are shown between $x=0$ and $x=5$ for $\mathrm{Co}-\mathrm{Re}-\mathrm{Sr} / \mathrm{SiO}_{2}(5-5-x / 100)$ catalysts.

Fig. 1 Static Chemisorptive Character and Catalytic Activity of Catalysts

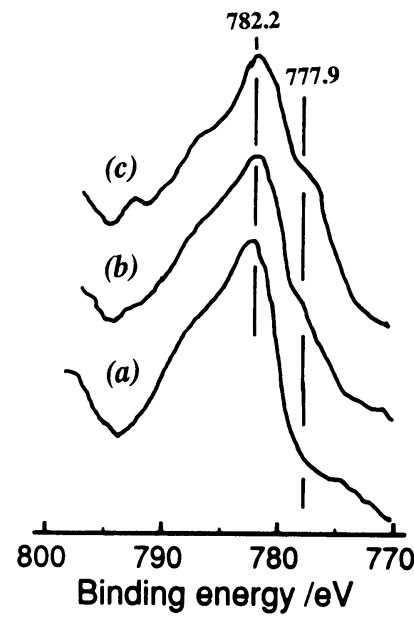

Fig. 2 XPS-Spectra of $\mathrm{Co}(2 \mathrm{p})$ of (a) $\mathrm{Co} / \mathrm{SiO}_{2}$, (b) $\mathrm{Co}-\mathrm{Re}-\mathrm{Sr} / \mathrm{SiO}_{2},(\mathrm{c}) \mathrm{Co}-\mathrm{Re} / \mathrm{SiO}_{2}$

比較のため硝酸コバルト $\left(\mathrm{Co}\left(\mathrm{NO}_{3}\right)_{2} \cdot 6 \mathrm{H}_{2} \mathrm{O}\right)$ を出発原料と した $\mathrm{Co} / \mathrm{SiO}_{2}$ の結果も示したが, $\mathrm{CO}$, 水素吸着量はともに小 さいにもかかわらず活性は著しく高く，この触媒の Co 分散度 が低いことを示唆している。

\section{1. 2. XPS}

Figs. 2 4 に各触媒の $\operatorname{Co}(2 \mathrm{p}), \operatorname{Re}(7 \mathrm{f})$ および $\operatorname{Sr}(3 \mathrm{~d})$ の XPS を示す。標準物質として測定した酢酸コバルト粉末は $782.4 \mathrm{eV}$ ，金属 Co 板は $779 \mathrm{eV}$ に Co $(2 \mathrm{p} 3 / 2)$ ピークを示し た ${ }^{14)}$ 。 $\mathrm{Co} / \mathrm{SiO}_{2}$ では $\mathrm{Co}^{2+}$ を示す約 $782 \mathrm{eV}$ のピークのみが得 られたことから, $\mathrm{Co} / \mathrm{SiO}_{2}$ 上の $\mathrm{Co}$ は 2 価のままほとんど還 元されずに酢酸コバルトに類似した電子状態を保持しているこ 


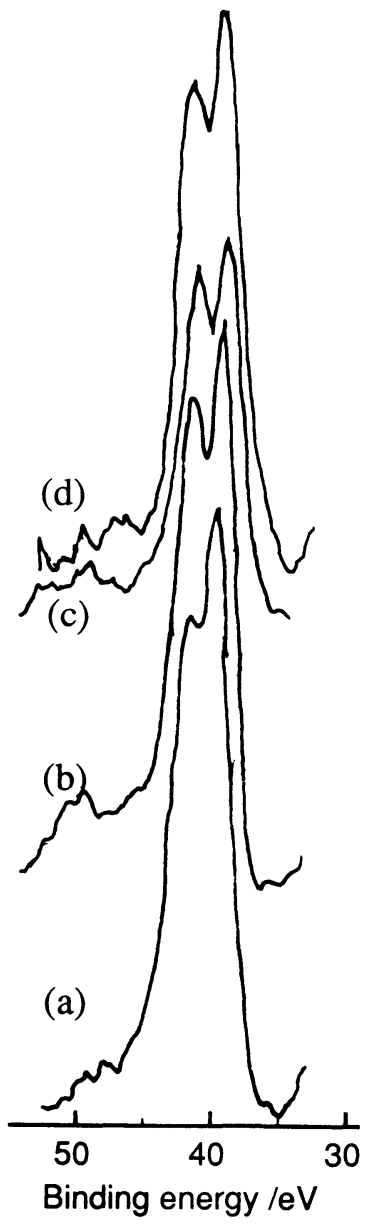

Fig. 3 XPS-Spectra of $\operatorname{Re}(4 \mathrm{f})$ of (a) $\mathrm{Re} / \mathrm{SiO}_{2}$, (b) $\mathrm{Co}-\mathrm{Re} / \mathrm{SiO}_{2}$, (c) $\mathrm{Co}-\mathrm{Re}-\mathrm{Sr} / \mathrm{SiO}_{2}$ before Use, and (d) $\mathrm{Co}-\mathrm{Re}-\mathrm{Sr} / \mathrm{SiO}_{2}$ after Use

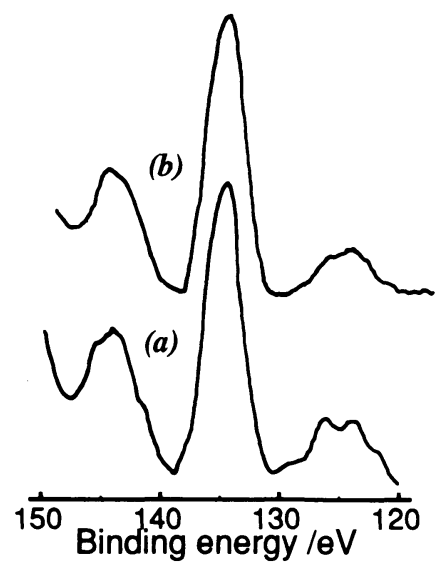

Fig. 4 XPS-Spectra of $\mathrm{Sr}(3 \mathrm{~d})$ of $\mathrm{Co}-\mathrm{Re}-\mathrm{Sr} / \mathrm{SiO}_{2}$ before (a) and after (b) Use

とがわかる7)。一方, $\mathrm{Co}-\mathrm{Re} / \mathrm{SiO}_{2}$ では $\mathrm{Co}$ 金属によると思わ れる約 $778 \mathrm{eV}$ 付近のショルターが観測され, Co の一部が還 元されていることを示している。すなわち, Re の存在が Co の還元を援けていることは明らかである。 $\mathrm{Co}-\mathrm{Re}-\mathrm{Sr} / \mathrm{SiO}_{2}$ で もこのショルターは見られるが, $\mathrm{Co}-\mathrm{Re} / \mathrm{SiO}_{2}$ に比べると小さ
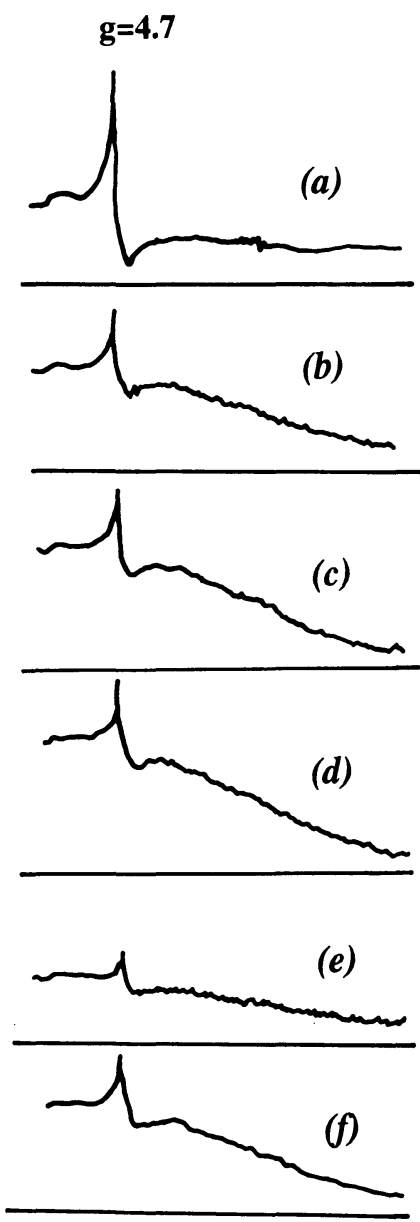

(a) standard solution $\left(\mathrm{Co}\left(\mathrm{OCOCH}_{3}\right)_{2} \cdot 4 \mathrm{H}_{2} \mathrm{O}+\right.$ pyridine, in toluene). (b) $\mathrm{Co}\left(\mathrm{OCOCH}_{3}\right) / \mathrm{SiO}_{2}(5 / 100)$, unreduced. (c) $\mathrm{Co} / \mathrm{SiO}_{2}(5 / 100)$, reduced at $450^{\circ} \mathrm{C}$. (d) $\mathrm{Co}-\mathrm{Sr} / \mathrm{SiO}_{2}$ $(5-5 / 100)$, reduced at $450^{\circ} \mathrm{C}$. (e) $\mathrm{Co}-\mathrm{Re} / \mathrm{SiO}_{2}(5-5 / 100)$, reduced at $450^{\circ} \mathrm{C}$. (f) $\mathrm{Co}-\mathrm{Re}^{-} \mathrm{Sr} / \mathrm{SiO}_{2}(5-5-5 / 100)$, reduced at $450^{\circ} \mathrm{C}$.

Fig. 5 ESR Signals of Catalysts

いので, Sr が Go の還元を抑制する効果を持つと考えられ る。なお, 実際の CO 水素化反応の場合には反応直前の触媒 の再還元を $450^{\circ} \mathrm{C}$ で行っているが, XPS 測定の場合 in situ 再 還元は装置上の限界のために $300^{\circ} \mathrm{C}$ 程度でしか行えないの で, 実際の反応中の Co 還元度は XPS から得られた $\mathrm{Co}^{0}$ と $\mathrm{Co}^{2+}$ の比よりも高いと思われる。

一方, Reについてはどの $\operatorname{Re}$ 含有触媒もほほ $40.1 \mathrm{eV}$ (4f7/2) にシャープなピークを有し, 文献值 ${ }^{14)}$ の金属 $\operatorname{Re}$ とよ く一致した。また, $\mathrm{Sr} 134.7 \mathrm{eV}(3 \mathrm{~d})$ のピークが得られ, $3 \mathrm{~d} 5 / 2$ と $3 \mathrm{~d} 3 / 2$ ピークの分離は見られなかったが, 文献値 ${ }^{14)}$ の 2 価の $\mathrm{Sr}$ のピークと一致した。Sr は酸化物として存在し ているものと思われる。

なお, $\mathrm{Ru}_{3}(\mathrm{CO})_{12}$ や $\mathrm{Ir}_{4}(\mathrm{CO})_{12}$ を $\mathrm{Ru}$ や Ir の出発原料とし た $\mathrm{Co}-\mathrm{Ru} / \mathrm{SiO}_{2}$ および $\mathrm{Co}-\mathrm{Ir} / \mathrm{SiO}_{2}$ 触媒についてもほほ同様の 結果が得られている ${ }^{12), 13) 。 ~}$

3. 1. 3. ESR

標準試料から得られた Co( II ) を示す $g=4.7$ の ESR シグ 


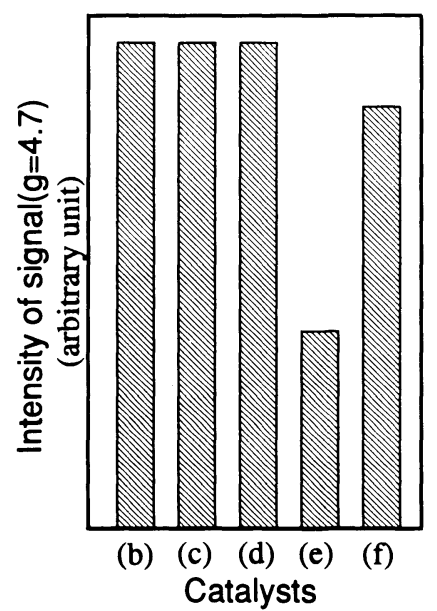

Fig. 6 Intensities of ESR Signals of Co ( II ) $(g=4.7)$ of the Same Catalysts as Shown in Fig. 5

ナルを各触媒について比較した。各 ESR シグナルを Fig. 5 に，またこれらシグナルの相対強度の比較を Fig. 6 に示す。 $\mathrm{Re}$ を含まない $\mathrm{Co} / \mathrm{SiO}_{2}$ および $\mathrm{Co}-\mathrm{Sr} / \mathrm{SiO}_{2}$ の $\mathrm{Co}^{2+}$ のシグナ ル強度は, $450^{\circ} \mathrm{C}$ で水素処理したにもかかわらず未処理の Co $\left(\mathrm{OCOCH}_{3}\right)_{2} / \mathrm{SiO}_{2}$ の強度とほとんど変わらなかった。しか し, $\mathrm{Co}-\mathrm{Re} / \mathrm{SiO}_{2}$ ではシグナル強度は大幅に減少し, Co の還 元が進んでいることを示している。 $\mathrm{Co}^{2+}$ 以外の $\mathrm{Co}$ 種が $\mathrm{Co}^{0}$ とすると, Co の $50 \%$ 以上が金属にまで還元されていること になる（還元度約 59\%）。これにさらに Sr を添加した触媒で はシグナル強度は増大し, $\mathrm{Co} / \mathrm{SiO}_{2}$ と $\mathrm{Co}-\mathrm{Re} / \mathrm{SiO}_{2}$ の中間の 值を示した（還元度約 $13 \%$ )。これらの結果は, $\operatorname{Re}$ の存在が $\mathrm{Co}^{2+}$ の還元を援け, Sr が Co の還元を抑制するという XPS の結果を支持するものである。

\section{1. 4. VIS}

Fig. 7 に各触媒の VIS スペクトルを示す。 $\mathrm{Co} / \mathrm{SiO}_{2}$ は $450^{\circ} \mathrm{C}$ で $\mathrm{H}_{2}$ 処理を施した後でも青色を呈しており，100 $\mathrm{C}$ で 乾燥処理しただけの $\mathrm{Co}\left(\mathrm{OCOCH}_{3}\right)_{2} / \mathrm{SiO}_{2}$ と同じく 525,590

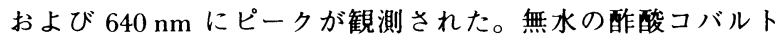
（青色）は, 各頂点に酸素を配位した四配位の Co（II）の構造 を持つと考えられているが, $\mathrm{Co} / \mathrm{SiO}_{2}$ の Co は $450^{\circ} \mathrm{C} て ゙ \mathrm{H}_{2}$ 処理した後でも，この $\mathrm{Co}$ ( II ) と類似の構造を保っていると 思われる。これらのピークは $\operatorname{Re} の$ 共存する触媒（黒色）では ほとんど見られなくなることからも, Re の添加により Co の 構造および電子状態が変化することを示している。

\section{1.5. 水菒気流中の TG 测定}

各触媒の水素気流中での TG スペクトルを Fig. 8 に示す。 $\mathrm{Co} / \mathrm{SiO}_{2}$ では, $350^{\circ} \mathrm{C}$ 付近で酢酸の分解によると思われる重量 減少（B）を経た後, $800^{\circ} \mathrm{C}$ 付近に小さいがはっきりした重量 減少 $(\mathrm{C})$ が観測された。この時の放出成分を質量分析したと ころ水であった。この変化は $\mathrm{Sr}$ を加えた触媒ではさらに約 $30^{\circ} \mathrm{C}$ 高温側にシフトした。これらの触媒は $500^{\circ} \mathrm{C}$ 水素処理後 でも Co( II ) を示す青色を保っているが, TG 測定後の試料は 黒色に変わっていることからも, Co は $800^{\circ} \mathrm{C}$ 付近で 0 価に還 元されたものと考えられる。すなわち, $\mathrm{Co} / \mathrm{SiO}_{2}$ は酢酸コバ ルトの分解後もCo と酸素の結合は保持されて 2 価のまま担

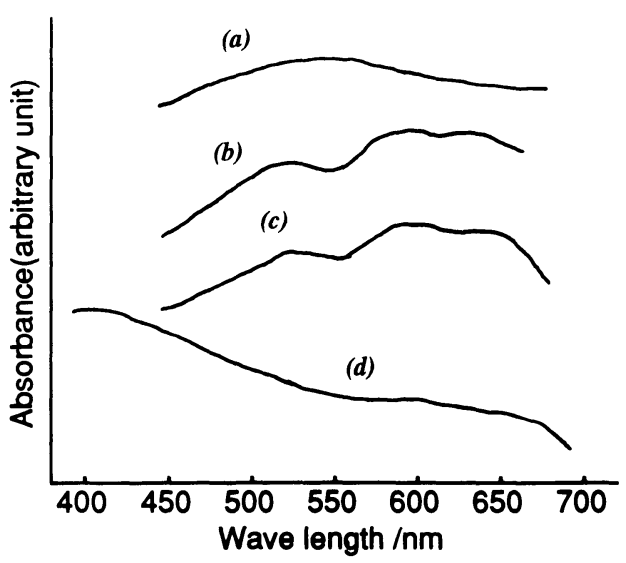

(a) $\mathrm{SiO}_{2}$, (b) $\mathrm{Co}\left(\mathrm{OCOCH}_{3}\right)_{2} / \mathrm{SiO}_{2}(5 / 100)$, dried at $100^{\circ} \mathrm{C}$, (c) $\mathrm{Co} / \mathrm{SiO}_{2}(5 / 100)$, after treated with flowing $\mathrm{H}_{2}$ at $450^{\circ} \mathrm{C}$, (d) $\mathrm{Co}-\mathrm{Re} / \mathrm{SiO}_{2}(5-5 / 100)$, treated with flowing $\mathrm{H}_{2}$ at $450^{\circ} \mathrm{C}$.

Fig. 7 Transmission Electronic Spectra of Catalysts

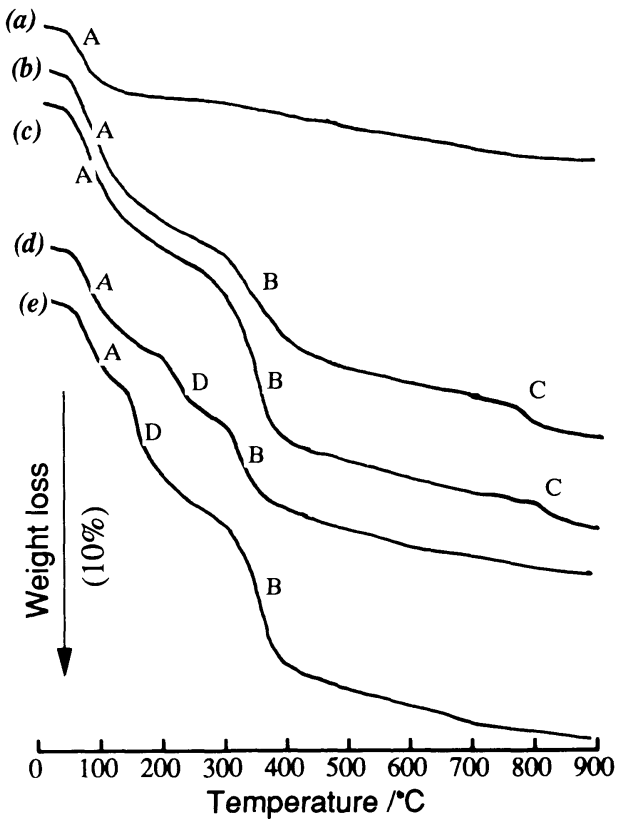

$\mathrm{H}_{2}$ flow rate: $50 \mathrm{ml} / \mathrm{min}$, temperature program rate : $20^{\circ} \mathrm{C} / \mathrm{min}$. (a) $\mathrm{SiO}_{2},\left(\right.$ b) $\mathrm{Co} / \mathrm{SiO}_{2}(5 / 100)$, (c) $\mathrm{Co}-\mathrm{Sr} / \mathrm{SiO}_{2}$ (5-5/100), (d) $\mathrm{Co}^{-\mathrm{Re}} / \mathrm{SiO}_{2}(5-5 / 100),\left(\right.$ e) $\mathrm{Co}-\mathrm{Re}-\mathrm{Sr} / \mathrm{SiO}_{2}$ $(5-5-5 / 100)$.

Fig. 8 TG Profiles of Catalysts under $\mathrm{H}_{2}$ Atmosphere

体の $\mathrm{SiO}_{2}$ と強く結合し, $800^{\circ} \mathrm{C}$ 程度までは安定に存在し続け るものと考えられる。

一方, $\mathrm{Co}-\mathrm{Re} / \mathrm{SiO}_{2}$ では $800^{\circ} \mathrm{C}$ 付近での重量减少 $(\mathrm{C})$ が観 測されなくなると同時に, 酷酸分解温度 (B) も $308^{\circ} \mathrm{C}$ とかな り低温側にシフトした。 $150^{\circ} \mathrm{C}$ 前後の重量隇少 $(\mathrm{D})$ は, $\mathrm{Re}$ 塩の分解による $\mathrm{Re}$ 金属への還元によるものと思われる。これ にさらに $\mathrm{Sr}$ を添加すると酢酸の分解温度 (B) が $357^{\circ} \mathrm{C}$ 付近 まで上昇するが, $800^{\circ} \mathrm{C}$ 付近での重量変化は認められなかっ 
た。この結果から, $\mathrm{Re}$ が存在すると $\mathrm{SiO}_{2}$ 上の酢酸コバルト は分解を受け易くなり，比較的低温で金属状にまで還元される のであろう。Sr はこの分解および還元を抑制する方向で働く ものと考えられる。

\section{1. 6. XRD}

各触媒の XRD スペクトルを Fig. 9 に示す。 $\mathrm{Co} / \mathrm{SiO}_{2}$ およ び $\mathrm{Co}-\mathrm{Sr} / \mathrm{SiO}_{2}$ では $\mathrm{Co}$ を示すピークは全く認められなかっ た。これらの触媒において，Co は高分散状態にあるか，ある いは非晶質であるかのどちらかであることを示しているが, 我々は既にこのようにして調製した $\mathrm{Co} / \mathrm{SiO}_{2}$ では Co 種が 2 価のまま超高分散担持されていることを明らかにしてい る $^{6), 7)} \mathrm{Re} / \mathrm{SiO}_{2}$ では，6 本のピークが観測されたがいずれも $\operatorname{Re}$ 金属の回折パターンによく一致した。この回折ピークの半 值幅から計算した $\operatorname{Re}$ 金属の結晶子径は約 $5.5 \mathrm{~nm}$ であった。 $\mathrm{Co}-\mathrm{Re} / \mathrm{SiO}_{2}$ および $\mathrm{Co}-\mathrm{Re}-\mathrm{Sr} / \mathrm{SiO}_{2}$ ではピーク強度は低下す るものの, Re 金属による回折ピークのみが認められたたこと から, Co は Re の存在により一部金属状に還元されているに もかかわらず $\mathrm{SiO}_{2}$ 上に高分散担持されており，一方 $\mathrm{Re}$ は金 属状で低分散担持されていると考えられる。Co 種のピークが 観測されなかったことから, Co の結晶子径は $2 \mathrm{~nm}$ 以下と推 定される。なお， Sr 含有触媒についても $\mathrm{Sr}$ 種を示す回折線は 全く観測されなかった。Sr XPS の測定から酸化物として存 在しており, 高分散担持されていることは考え難いので, 非晶 質と考えられる。

既に報告したように7)，酢酸コバルトから調製した $\mathrm{Co} / \mathrm{SiO}_{2}$ では，硝酸コバルトや塩化コバルトから調製した $\mathrm{Co} / \mathrm{SiO}_{2} に$ 比べて Co の分散度が極めて高いことが特徴であったが，ここ で Re 共存下で Co が金属に還元されても Co の高分散が維持 されていることが明らかにされた。このことは，後に議論する

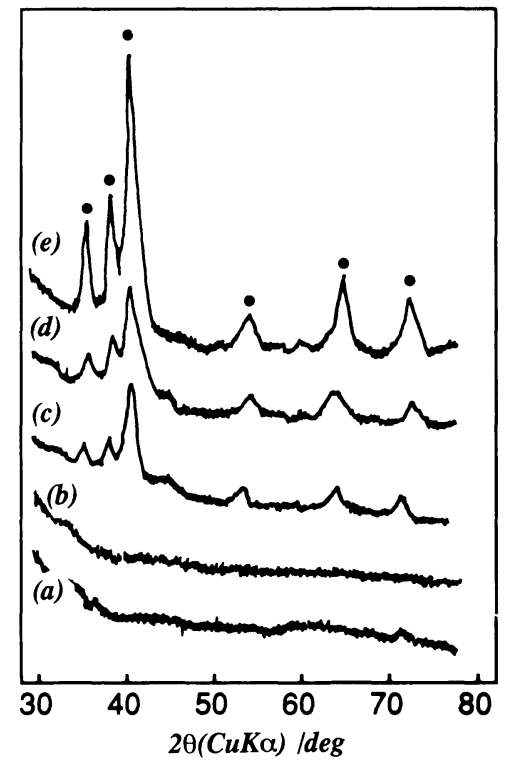

Dots are assigned to $\mathrm{Re}$ metal. (a) $\mathrm{Co} / \mathrm{SiO}_{2}$, (b) $\mathrm{Co}-\mathrm{Sr} / \mathrm{SiO}_{2}$, (c) $\mathrm{Co}-\mathrm{Re}-\mathrm{Sr} / \mathrm{SiO}_{2}$, (d) $\mathrm{Co}-\mathrm{Re} / \mathrm{SiO}_{2}$, (e) $\mathrm{Re} / \mathrm{SiO}_{2}$

Fig. 9 XRD-Spectra of Catalysts Measured in Air after $\mathrm{H}_{2}$ Treatment at $450^{\circ} \mathrm{C}$
ように，本触媒の性能上重要な特徴であると考えられる。

3. 1. 7. パルス法による CO 吸着量の測定と吸着 CO の 昇温還元スペクトル

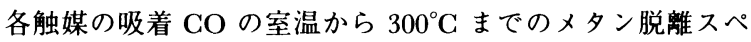
クトルを Fig. 10 に示した。また, 各触媒についてパルス法 による CO 吸着量およびメタン脱離ピーク温度を Table 1 に まとめた。 $\mathrm{Co} / \mathrm{SiO}_{2}$ では $\mathrm{CO}$ 吸着量が極めて小さく, メタン の脱離ピークも得られなかった。 $\mathrm{Co}-\mathrm{Re} / \mathrm{SiO}_{2}$ では $\mathrm{CO}$ 吸着量 が 10 倍以上増加し, $187^{\circ} \mathrm{C}$ をピークとするシャープなメタン 脱離スペクトルが得られた。これに微量の Sr の添加により $\mathrm{CO}$ 吸着量は䄪 $1 / 3$ に激減し, $\mathrm{Sr}$ 添加量の増大とともに吸着 量は漸減傾向となり, メ夕ン脱離ピーク温度も低下傾向を示し た。しかし，どの場合もメタン脱離開始温度に変化はなく， $\mathrm{Co}-\mathrm{Re} / \mathrm{SiO}_{2}$ の場合に $150^{\circ} \mathrm{C}$ 付近にショルダーが認められるの で,これら脱離ピークは二つのピークからなると推定できる。 その場合, Sr の添加により高温側のピークが大きく隇少し, その結果として脱離ピーク温度が低下すると考えられる。CO 水素化反応において $\mathrm{Sr}$ の添加により炭化水素の生成のみが大 きく抑制されたが, その結果と高温側のメタン脱離ピークの減 少とはよく対応している。炭化水素生成活性の低下が触媒の

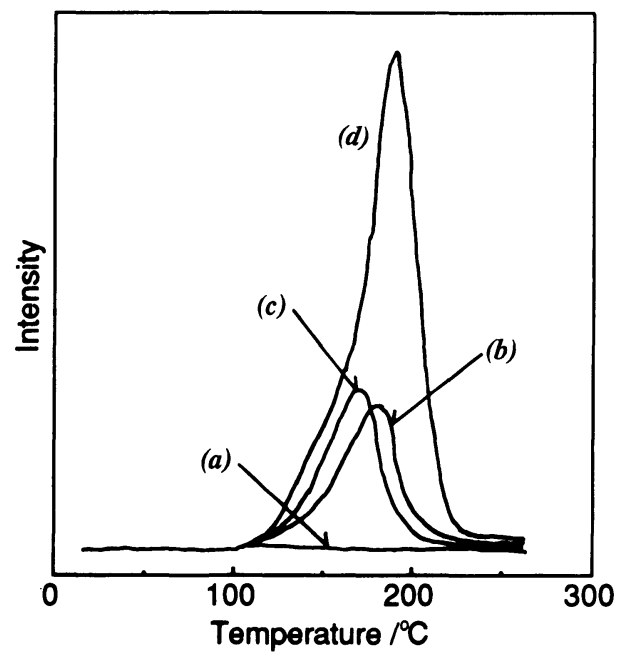

$\mathrm{H}_{2}$ flow rate : $60 \mathrm{ml} / \mathrm{min}$, temperature program rate : $7.5^{\circ} \mathrm{C} / \mathrm{min}$. (a) $\mathrm{Co} / \mathrm{SiO}_{2}(5 / 100)$, (b) $\mathrm{Co}-\mathrm{Sr} / \mathrm{SiO}_{2}(5-5 / 100)$, (c) $\mathrm{Co}-\mathrm{Re}-\mathrm{Sr} / \mathrm{SiO}_{2}(5-5-0.5 / 100)$, (d) $\mathrm{Co}-\mathrm{Re}-\mathrm{Sr} / \mathrm{SiO}_{2}$ (5-5-5/100), (e)Co- $\mathrm{Re} / \mathrm{SiO}_{2}(5-5 / 100)$.

Fig. 10 TPR Profiles of Adsorbed CO

Table 1 Adsorption Volumes of CO by Pulse Method and Desorption Temperature of $\mathrm{CH}_{4}$

\begin{tabular}{ccccc}
\hline \multicolumn{3}{c}{$\begin{array}{c}\text { Catalyst component } \\
{[\mathrm{wt} \%}\end{array}$ to $\left.\mathrm{SiO}_{2}\right]$} & $\begin{array}{c}\text { Adsorbed vol. } \\
\text { of } \mathrm{CO}\end{array}$ & $\begin{array}{c}\text { Desorpt. temp. } \\
\text { of } \mathrm{CH}_{4}\end{array}$ \\
$\mathrm{Co}$ & $\mathrm{Re}$ & $\mathrm{Sr}$ & {$[\mathrm{ml} / \mathrm{g} \cdot$ catalyst $]$} & {$\left[{ }^{\circ} \mathrm{C}\right]$} \\
\hline 5 & 0 & 0 & 0.18 & - \\
5 & 5 & 0 & 2.65 & 187 \\
5 & 5 & 0.5 & 0.91 & 181 \\
5 & 5 & 1 & 0.67 & 175 \\
5 & 5 & 2 & 0.88 & 166 \\
5 & 5 & 5 & 0.78 & 176 \\
\hline
\end{tabular}


$\mathrm{CO}$ 解離吸着能の低下によるとすれば'5), 高温側ピークは $\mathrm{CO}$ 解離型, 低温側のそれは CO 非解離型吸着サイトとも考えら れるが, それよりも反応条件下での FTIR の研究において Sr の添加によりリニア CO 種の大きな滅少が観察されているこ とから ${ }^{11)}$, 低温側はブリッジ CO 種, 高温側はリニア CO 種 と考えた方がよいと思われるが，この点は明確ではない。

なおこのパルス法による CO 吸着量と既に述べた静置法 による CO 吸着量との間には, 触媒によってはかなりの差異 が見られたが,この差はパルス法では吸着平衡状態になってい ないことによるものと考えられる。このことは，触媒によって $\mathrm{CO}$ の吸着力の異なるサイトが複数存在していることを示唆す るものと思われる。

\section{2. Co の還元過程}

酢酸コバルトから調製した $\mathrm{Co} / \mathrm{SiO}_{2}$ は $450 \sim 500^{\circ} \mathrm{C}$ で水素 処理を施した後でも Co は 2 価の状態を保っており, TG の結 果からこの状態の $\mathrm{Co}$ ( II ) は水素中 $800^{\circ} \mathrm{C}$ 位までは安定に存 在すると思われる。EXAFSによる検討結果》) およびXPS, VIS の結果から，この Co（II）は酢酸コバルトに類似した配 位構造および電子構造を持つと考えられた。これらの結果から Co の状態の変化を Scheme 1 のように推定した7)。 $\mathrm{SiO}_{2}$ 上の Co は $400 \sim 500^{\circ} \mathrm{C}$ で水素処理後も酢酸コバルトに類似した構 造を保ちながら酸素原子を介して担体の $\mathrm{SiO}_{2}$ と強く結合して いるために, 水素中, 高温下でも 2 価のまま高分散状態で安 定に存在するものと思われる。

これに Re が共存した場合, この $\mathrm{Co}$ ( II ) の一部が $450^{\circ} \mathrm{C}$ までに高分散のまま水素還元されることがわかった。 Re が Co の還元に寄与していることは明らかである。Reは水素の 活性化能の高い貴金属の一つであり, この場合は Re 金属上で
活性化された水素が Co（II）を還元する，いわゆるスピル オーバー効果によるものと考えられる。主として TG の結果 から, $\mathrm{Co}-\mathrm{Re} / \mathrm{SiO}_{2}$ に扔ける $\mathrm{Co}$ 還元過程はたとえば Scheme 2のように考えられる。これにさらに Sr が共存した場合に は, Reによる $\mathrm{Co}$ ( II ) の還元は抑制される方向で働くが, そ の原因の一つとして Sr が水素の移動を妨害することが考えら れる。

\section{3. $\mathrm{Co}-\mathrm{Re}-\mathrm{Sr} / \mathrm{SiO}_{2}$ 触媒の活性点と各成分の役割}

既に報告したように，硝酸コバルトから調製した $\mathrm{Co} / \mathrm{SiO}_{2}$ は高い高級炭化水素生成活性を持ち, $\mathrm{SiO}_{2}$ 上の $\mathrm{Co}$ は金属状 に還元されていた7)。それに対し，酢酸コバルトを出発原料と した $\mathrm{Co} / \mathrm{SiO}_{2}$ は $\mathrm{Co}$ の分散度が高いことを特徴とするが, 活 性は極めて小さく, その理由として Co が還元されずに 2 価 のまま $\mathrm{SiO}_{2}$ 上に存在しているためであると考えられた。一 方, $\mathrm{Re} / \mathrm{SiO}_{2}$ は $\mathrm{Re}$ が金属状であるにもかかわらず本条件下で は活性が小さく，生成物は主として低級炭化水素であった。 $\mathrm{Co}-\mathrm{Re} / \mathrm{SiO}_{2}$ は $\mathrm{Co}, \mathrm{Re}$ 各々単独の場合に比べて数十倍の活性 を示すようになり，炭化水素のほかに含酸素化合物も生成する ようになったことから, Co と Re の共存により新たな活性点 が生成されたことは明らかである。

3. 2. で議論したように, Go の一部が Re の共存によって金 属状に還元されることが明らかとなった。一方, Co の共存に よる Re の状態の変化は XRD, XPS の測定からは認められな かった。また, Co-Re のバイメタリックなサイトの存在に関 する情報は得られなかった。これらの結果だけから Re の状態 の変化やバイメタリックサイトの存在, あるいはこれらが CO 水素化反応の主活性種であること等を否定することはできな い。しかし，硝酸コバルトや $\mathrm{Co}_{2}(\mathrm{CO})_{8}$ から調製した
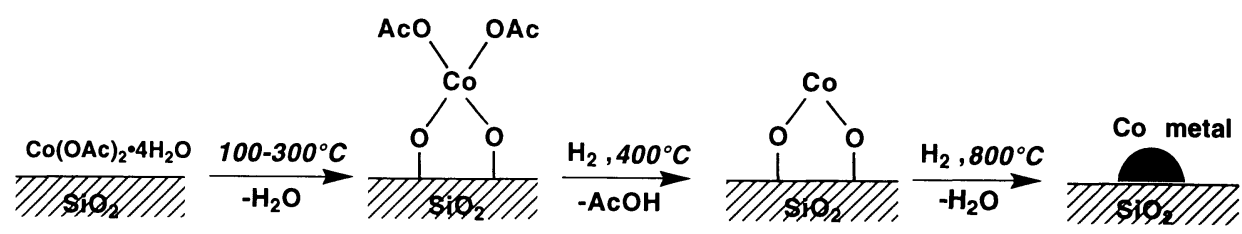

Ac : $\mathrm{CH}_{3} \mathrm{CO}$.

Scheme 1 The Proposed Reduction Procedure of Co Species on $\mathrm{Co} / \mathrm{SiO}_{2}$
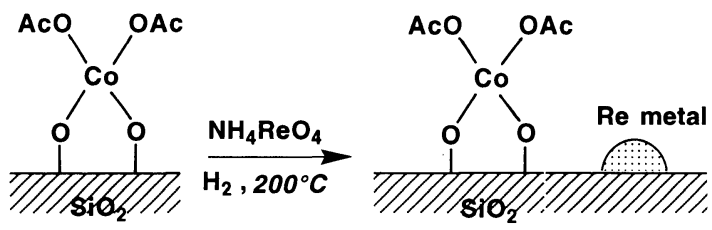

Ac : $\mathrm{CH}_{3} \mathrm{CO}$

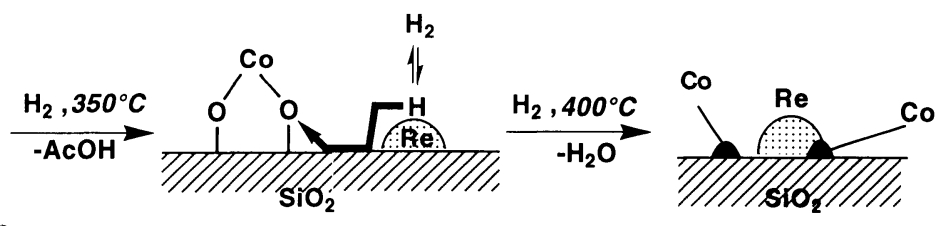

Scheme 2 The Proposed Reduction Procedure of Co Species on Co- Re $/ \mathrm{SiO}_{2}$ 
$\mathrm{Co} / \mathrm{SiO}_{2}$ が高い活性を持つことから ${ }^{16)}$, 本来金属状 Co の活 性は高いと考えられる。また, 単独で $\mathrm{SiO}_{2}$ に担持した場合の 触媒としての性質がそれぞれ全く異なる Ru および Ir を Re の代わりに用いた触媒についても， Ru や Ir が上段で述べた $\operatorname{Re}$ の効果と極めて類似した効果を持つことが認められてお $\eta^{12), 13)}$, これら 3 種類の触媒の主たる活性種が同一であるこ とを示唆している。以上の結果から, 金属状 Co がこれらの触 媒の共通の主活性種であるとするのが最も妥当な結論であると 思われる。Sr 添加による Co 還元度の低下と活性の低下, CO や水素の吸着量と活性の相関性などの結果は, いずれもこの推 論と矛盾しない。また, 既に報告した本触媒系の反応条件下に おける吸着 COの FTIRによる研究からも, Reや Sr サイト の $\mathrm{CO}$ 転化反応に対する寄与は小さいと考えられた ${ }^{11)}$ 。さら に, $\mathrm{Co}_{2}(\mathrm{CO})_{8}$ を出発原料とした $\mathrm{Co} / \mathrm{SiO}_{2}$ 触媒は, $\mathrm{Re}$ 等の共 存なしでも $\mathrm{Co}-\mathrm{Re} / \mathrm{SiO}_{2}$ 触媒と類似した活性と生成物分布を 示し, $\mathrm{Sr}$ の添加効果も極めて類似していた ${ }^{8)}$ 。これらの結果は いずれも本触媒系において金属 Co が主たる活性種であること を支持するものである。XRD の結果は $\mathrm{Re} や \mathrm{Sr}$ が共存し, Co の一部が還元された後でも Co 分散度の大きな低下はない ことを示している。すなわち, 本触媒系における含酸素化合物 生成の主活性種は高分散 Co 金属であると考えられる。ここ で, Reは主活性種である Co の還元を援けることにより触媒 を活性化する役割を果たす，と結論される。

Co が単独で含酸素化合物生成の主活性種であるとする上の 結論は, Co 触媒は高級炭化水素指向の触媒であるというこれ までの通説とは異なっている。しかし，これまでのほとんどの Co 触媒に関する研究は硝酸コバルトまたは塩化コバルトを出 発原料に用いた触媒であり，酢酸コバルトから調製した Co 触 媒がこれらとは全く異なる性質をもつことは既に議論した通り である。実際, その詳細は不明であるが Hoechst 社の特許で は酢酸コバルトから調製した修飾 Co 触媒が高いエ夕ノール収 率を示している4)。我々はまた, $\mathrm{Co}_{2}(\mathrm{CO})_{8}$ から調製した $\mathrm{Co} / \mathrm{SiO}_{2}$ が $\mathrm{Sr}$ 等で修飾することにより高いエタノール選択率 が得られることを既に報告しているが，Yermakov らも $\mathrm{Co}_{2}$ $(\mathrm{CO})_{8}$ を $\mathrm{TiH}$ や $\mathrm{ZrH}$ で修飾した $\mathrm{SiO}_{2}$ に担持することによ り高いエタノール選択率が得られることを示した5)。酢酸コバ ルトから調製された $\mathrm{Co} / \mathrm{SiO}_{2}$ においては, $\mathrm{Co} は \mathrm{SiO}_{2}$ 上に高 分散されていることが硝酸コバルトや塩化コバルトから調製し た $\mathrm{Co} / \mathrm{SiO}_{2}$ とは際立って異なる特徵であることは既に別報で 議論した ${ }^{7)}$ 。また, $\mathrm{Co}_{2}(\mathrm{CO})_{8}$ から調製した $\mathrm{Co} / \mathrm{SiO}_{2}$ の $\mathrm{Co}$ が 高分散担持されることはよく知られている。Hoechst 社や Yermakov らの触媒も含めてこれらの Co 触媒が高いエタノー ル生成能を持つことは, 高い Co 分散度と密接な関係があるも のと考えられる。 $\mathrm{Rh} / \mathrm{SiO}_{2}$ 触媒の場合, $\mathrm{Rh}$ 分散度は生成物分 布に影響を与えたが ${ }^{17)}$, Co 触媒の場合も生成物分布に対する Co 分散度の効果は大きいものと思われる。反応機構の詳細は 現時点では解明されていないが, Co が高分散することによ り, CO の解離能を弱め, 連鎖成長を抑制するなど, 含酸素化 合物，特にエ夕ノールの生成に有利な条件をもたらすことにな るのであろう。

$\mathrm{Sr}$ もまた本触媒系において, 含酸素化合物の選択的合成の ために不可欠な成分である。Sr の添加は触媒の活性を低下さ
せたが，特に炭化水素の生成速度の低下が大きく，含酸素化合 物, 特にエタノールの選択率を大幅に向上させた。XPS の結 果から, Sr 2 価カチオンとして存在しており, 主活性種と 思われる Co の還元を抑制することがわかった。また, Srの 添加が触媒の CO 吸着能を低下させたが, 炭化水素の生成能 を低下させることから CO の解離吸着能を低下させると考え られる ${ }^{15)}$ 。さらに, 反応条件下における FTIR の研究から, $\mathrm{Sr}$ の添加により Coへのリニア CO 吸着種が大幅に隇少する が, ブリッジ CO 種はほとんど変わらなかった ${ }^{11}$ 。また, 酢 酸コバルトからの $\mathrm{Co}-\mathrm{Ir} / \mathrm{SiO}_{2}$ 触媒や $\mathrm{Co}_{2}(\mathrm{CO})_{8}$ からの $\mathrm{Co} / \mathrm{SiO}_{2}$ 触媒についての研究から, $\mathrm{Sr}$ の添加が触媒調製過程 での Co 粒子の凝集を抑えて Co の高分散を保持する効果を有 すると考えられた ${ }^{13), 16)}$ 。これらの結果を総合すると, Sr は炭 化水素生成に有利な活性サイト（大きな粒子径の Co 金属粒子 などがこれにあたると考えられる）の生成を選択的に抑えるだ けでなく, Co の電子状態をコントロールしており, それが触 媒の水素化能や CO 解離吸着能を低下させて炭化水素の生成 を抑える役割を果たしている可能性を示している。すなわち Sr は, 高分散 Co 触媒による CO 水素化反応において含酸素 化合物生成の中間体と考えられるアシル吸着種の安定性を高 め，そのことがアシル中間体からヒドロキシアルキル中間体を

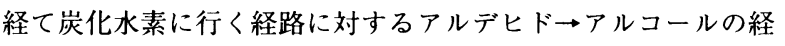
路の比率を相対的に高めることになるものと考えられる。

\section{4. 結 論}

一酸化炭素の水素化においてエ夕ノール生成活性の高い $\mathrm{Co}-\mathrm{Re}-\mathrm{Sr} / \mathrm{SiO}_{2}$ 触媒のキャラクタリゼーションを行い, 以下 の結論を得た。

1）エタノールおよび炭化水素生成の主活性種は高分散した Co 金属である。

2) $\mathrm{Re}$ は不活性な $\mathrm{Co}^{2+}$ 種が高分散を保持したまま活性な $\mathrm{Co}^{0}$ に還元されるのを援ける。

3）Sr は 2 価カチオンとして存在しており, 主活性種である Co 種の分散状態と電子状態を制御することにより, 触媒の $\mathrm{CO}$ 解離吸着能や水素化能を弱め, アシル中間体の安定性を高 める等の効果を持つと考えられる。

\section{References}

1) Anderson, R. B., "Fischer-Tropsch Synthesis", Academic Press, Orland (1984), p. 122.

2) Herman, R. G., "New Trends in CO Activation, Studies on Surface Science and Catalysis 64", ed. by Guczi, L., Elsevier, Amsterdam (1991), p. 265.

3) Fujimoto, K., Oba, T., Appl. Catal., 13, 289 (1985).

4) Hachenberg, H., Wunder, F., Leupold, E. I., Schmidt, H. J., Eur. Pat. Appl. 21330 (1978).

5) Lisitsyn, A. S., Golovin, A. V., Chuvilin, A. L., Kuznetsov, V. L., Romanenko, A. V., Danilyuk, A. F., Yermakov, Yu. I., Appl. Catal., 55, 235 (1989).

6) Kintaichi, Y., Takeuchi, K., Matsuzaki, T., Hanaoka, T., Arakawa, H., Sugi, Y., Ito, T., Chemistry Express, 4, 129 (1989).

7) Takeuchi, K., Matsuzaki, T., Hanaoka, T., Arakawa, H., Sugi, Y., Matsubayashi, N., J. Nat. Chem. Lab. Ind., 84, 
549 ( 1989$)$.

8) Matsuzaki, T., Takeuchi, K., Hanaoka, T., Arakawa, H., Sugi, Y., Appl. Catal., 105, 159 (1993).

9) Takeuchi, K., Matsuzaki, T., Arakawa, H., Sugi, Y., Appl. Catal., 18, 325 (1985).

10) Matsuzaki, T., Takeuchi, K., Arakawa, H., Sugi, Y., Fukusima, T., Ichikawa, M., Sekiyu Gakkaishi, 29, (1) 84, (1986).

11) Arakawa, H., Takeuchi, K., Matsuzaki, T., Sugi, Y., Sekiyu Gakkaishi, 31, (4), 335 (1988).

12) Takeuchi, K., Matsuzaki, T., Arakawa, H., Hanaoka, T., Sugi, Y., Appl. Catal., 48, 149 (1989).

13) Matsuzaki, T., Takeuchi, K., Arakawa, H., Hanaoka, T.,
Sugi, Y., "Catalytic Science and Technology", Vol. 1, eds. by Yoshida, S., Takezawa, N., Ono, T., Kodansha, Tokyo and VCH, Weinheim (1991), p. 249.

14) Mulleuberg, G. E., ed., "Handbook of X-ray Photoelectron Spectroscopy", Perkin-Elmer Corp., Minnesota (1979), p. 52, 148, 96.

15) Ichikawa, M., Shokubai, 24, 212 (1982).

16) Takeuchi, K., Matsuzaki, T., Hanaoka, T., Arakawa, H., Sugi, Y., Wei, K., J. Mol. Catal., 55, 361 (1989).

17) Arakawa, H., Fukushima, T., Ichikawa, M., Takeuchi, K., Matsuzaki, T., Sugi, Y., Chem. Lett., 23 (1985).

Summary

\title{
Characterization of Co-Re-Sr/SiO 2 Catalyst Prepared from Cobalt Acetate as a Cobalt Precursor for CO Hydrogenation
}

\author{
Takehiko Matsuzaki, Kazuhiko Takeuchi, Taka-aki Hanaoka,
} Hironori Arakawa, and Yoshihiro Sugi

National Institute of Materials and Chemical Research, A. I. S. T. Research Center, Higashi 1-1, Tsukuba, Ibaraki 305

$\mathrm{Co}-\mathrm{Re}-\mathrm{Sr} / \mathrm{SiO}_{2}$ catalyst derived from cobalt acetate as a Co precursor was characterized using XRD, XPS, ESR, visible spectrum (VIS), TG, TPR, etc. to clarify the features of active species and the roles of the components of the catalyst. $\mathrm{Co}-\mathrm{Re} / \mathrm{SiO}_{2}$ catalyst possesses high activity for $\mathrm{CO}$ hydrogenation and produces oxygenates, especially ethanol with about $10 \%$ selectivity, as well as hydrocarbons, although $\mathrm{Co}$ and $\mathrm{Re}$ supported on $\mathrm{SiO}_{2}$ have a low activity. By addition of $\mathrm{Sr}$ to this catalyst, the yield of hydrocarbons is depressed and the selectivity of ethanol is greatly increased to $c a .25 \%$. From these results, it is clear that a new active site is generated by the mixing of Co with Re, and Sr depresses the formation of hydrocarbons and enhances the formation of ethanol.
The following results were obtained by the characterization: (1) A part of $\mathrm{Co}^{2+}$ particles on the support was reduced to $\mathrm{Co}^{0}$ by the coexistence of $\mathrm{Co}$ and $\mathrm{Re}$, while no change was observed for Re species. (2) Co particles kept high level of dispersion on $\mathrm{SiO}_{2}$. (3) Sr controlled the reduction of $\mathrm{Co}^{2+}$ to $\mathrm{Co}^{0}$. From these results, it was concluded that ( 1 ) the main active site of the catalyst is highly dispersed Co metal, (2) Re assists to reduce the $\mathrm{Co}^{2+}$ species on $\mathrm{SiO}_{2}$ to $\mathrm{Co}^{0}$ keeping Co particles highly dispersed, (3) Sr controls the electronic states of Co and decreases the hydrogenating ability of the catalyst, and then works to stabilize the acyl intermediate to form ethanol.

\section{Keywords}

Carbon monoxide, Hydrogenation, Alcohol, Composite catalyst, Supported cobalt catalyst, Characterization 